\title{
The Serbian armed forces as a factor of international cooperation and eurointegration
}

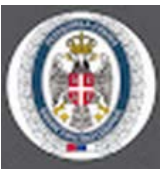

Received: 21/09/2021

Revised: 30/09/2021

Accepted: 03/10/2021

Published: 06/12/2021

Corresponding author:

Iris Bjelica-Vlajić

Correspondence email:

iris_bjelica_vlajic@yahoo.com

DOI: $10.5937 /$ vojdelo2103048V

\begin{tabular}{|l|l|l|l|}
\hline c & e & o & n \\
\hline c & e & e & s \\
\hline
\end{tabular}

\author{
Iris Bjelica-Vlajić \\ Univerzitet odbrane u Beogradu, Vojna akademija
}

\begin{abstract}
:
By concluding international agreements in the field of security and defence, the Serbian Armed Forces become a factor of international cooperation, which imposes certain responsibilities on the state and, in a special way, regulates the international legal position of their members. The paper presents the origin and development of the idea of the Common European Security and Defence, the obligations of the Republic of Serbia and the national legal framework that regulates this field. The goal of the EU Common Foreign and Security Policy, established by the Maastricht Treaty, is to preserve peace and strengthen international security in accordance with the principles of the United Nations Charter. To achieve this goal, the Common Security and Defence Policy has been developed, with the Union taking the leading role in peacekeeping operations and conflict prevention. The analysis of the content of national and international acts shows the evolutionary development of the idea on the existence of collective security, the acts for its implementation and the conditions necessary for the successful execution of the set tasks have been developed. Furthermore, comparative and historical methods have been used, as well as the method of deduction. It can be concluded that the new field of integration in Europe requires that the armed forces of the member states gain a role in international relations by initiating a series of institutional reforms and a change in the understanding of the social role of the military. International military engagement at regional and global level, along with bilateral cooperation, is a means of eliminating threats to national security while strengthening the capabilities of the national defence system. It is necessary to meet strict conditions for such engagement to be legitimate.
\end{abstract}

Keywords: Common Security and Defence Policy; European Union; Serbian Armed Forces

\section{INTRODUCTION}

The European Union (EU) was created on the idea of the economic development of the member states, which makes it difficult for those states to decide on integration in the fields that are traditionally related to sovereignty, so the Common Security and Defence Policy (CSDP) is the youngest in relation to other policies.

The idea of the collective security is not new, but it gained its momentum after the Second World War and the adoption of the United Nations Charter. The first goal of the United Nations is to maintain international peace and security. For such purpose, it is allowed to take effective collective measures to prevent and eliminate threats to peace and to suppress acts of aggression or other violations of peace, when this cannot be achieved by peaceful means, and in accordance with the principles of justice and international law. At the invitation of the Security Council, all members of the United Nations undertake the obligation to put their armed forces, assistance and benefits including the right of passage, necessary for the maintenance of international peace and security, at their disposal. When the Security Council decides on the use of force, it shall invite the member state not represented in the Council to participate in making the decisions related to the use of that member's contingent of the armed forces. The Charter provides for the establishment of the Military Staff Committee to give advice and assistance to the Security Council on all issues related to the military needs. The Military 
Staff Committee is composed of the Chiefs of Staff of the permanent members of the Security Council or their representatives. The membership in the United Nations does not forbid the regional association of its member states with regard to the common defence policy. Invoking this authority, after the end of the Second World War, on several occasions, attempts were made to organize European states in terms of the common defence policy, but they were not very successful.

The end of the Cold War and the dissolution of the SFRY showed that Europe is unprepared to successfully resolve crisis situations and that it is necessary to create a framework within which European armed forces can be engaged at regional level.

The Western European Union (WEU) has been a place of consultation on security and defence issues in Europe since its establishment. Within it, the European Security and Defence Identity (ESDI) began to develop, which, in 1999, was transformed into the European Security and Defence Policy (ESDP). The signing of the agreement known as the "Petersberg tasks" of the Western European Union Council in 1992 foresaw three situations in which the armed forces could be used: humanitarian and rescue missions, peacekeeping tasks and the use of force in the event of a crisis.

The coming into force of the Amsterdam Treaty in 1999, among other things, led to the establishment of new structures and tasks for the EU - the Common Foreign and Security Policy. The military tasks that the EU can undertake have been defined and the possibility of developing its future defence policy has been indicated, leaving a possibility that the members take a common position regarding security challenges. The most significant contribution of the Amsterdam Treaty to the Common Foreign and Security Policy is the introduction of the institution of the EU High Representative for Foreign Affairs and Security Policy. At the meeting of the European Council in Cologne, the members stated that the EU should have military capacities in order to respond to international crisis on its own. Institutional reforms have also been proposed.

The Lisbon Treaty is an amendment to previous treaties. It is important because it contains provisions related to the Common Foreign and Security Policy. The High Representative has also been given the function of the Vice-President of the European Commission and the Chairman of the Foreign Affairs Council. These two different functions provide the possibility to use all the necessary EU funds in resolving a crisis.

\section{THE EU COMMON SECURITY POLICY AND THE REPUBLIC OF SERBIA}

The process of accession of the Republic of Serbia to the European Union is taking place gradually, with the opening of 35 chapters in which the progress that the candidate state has made in certain fields is evaluated. In Chapter 31, one of the aspects of harmonization is related to the participation of the candidate in the Common Defence Policy of the Union: harmonization of Serbian legislation with the EU law, active participation in the EU missions, as well as contribution to building common security capabilities and maintaining common security in Europe.

The Common Security and Defence Policy is what emphasizes the supranational identity of the Union because it is not only a simple sum of its members, but also a special participant in international relations and a signatory of international agreements. By starting independent military missions, the Union becomes a recognized participant at the international scene, but the emphasis shifts from defence to the field of international or regional security.

The youngest common policy of the Union differs from other policies because for its implementation there are no directives that need to be incorporated into national legislation, but it approaches the previously adopted goals and contributes to their implementation. The participation of the Serbian Armed Forces members in the missions that the EU has in the world is an important element of statehood. The Armed Forces get a double role: the first is the justification of their engagement outside 
national borders, and the second is a means of foreign policy because it crosses the path from defence tasks to a means of preventing conflict and resolving a crisis.

\section{International legal framework}

The European Union Treaty, in the section on the Common Security and Defence Policy, defines crisis management operations as civilian and/or military operations taking place outside the Union borders in order to maintain peace, prevent conflict and strengthen international security in accordance with the principles of the United Nations Charter. The tasks covered by these operations are classified: joint disarmament operations, humanitarian and rescue tasks, military counseling and assistance, conflict prevention and peacekeeping, forces tasks in crisis management including peacemaking and post-conflict stabilization.

In 2013, the European Defence Agency (EDA) signed the Administrative Cooperation Agreement with Serbia, which enables the participation of the Republic of Serbia in the EDA projects and programmes. The same agreements have been signed with Norway, Switzerland and Ukraine. The participation in these operations of the Union imposes on the Serbian Armed Forces members the obligation to respect the principles of international law, and also the agreed scope of authority under the treaty. None of these treaties can affect the rights and obligations of the contracting parties under other international treaties and instruments establishing international courts and tribunals. The Republic of Serbia has regulated the participation of the armed and other defence forces in the EU missions by accepting the model of the provisional agreement, which regulates this matter in a general way. In addition to this international agreement, for the status and position of the Serbian Armed Forces members who participate in crisis management operations of the European Union, the agreements that the Union concludes with the host country are also important. The states whose members participate in an operation reserve the right to exercise criminal and disciplinary jurisdiction over their members in the territory of the host country in accordance with national law.

The participation of the Serbian Armed Forces members in the EU military crisis management operation is carried out on the basis of the decision of the Council and subsequent amendments. Serbia has the same rights and obligations regarding the everyday management of that operation as the member states of the European Union that participate in it. The senior military representative represents the Serbian contingent in the EU military crisis management operation. He will consult with the EU Force Commander on all issues affecting the operation and will be responsible for everyday discipline of the Serbian contingent. Through him, the Republic of Serbia will timely inform the Commander-inChief of the EU Operation about any change in its participation, and the Commander-in-Chief of the EU Operation can, after consultation with the Republic of Serbia, request the withdrawal of its contingent at any time. Although the personnel deployed by the Republic of Serbia performs its duties and acts solely in the interest of the particular EU military crisis management operation, during the mission, all forces and personnel participating in that EU operation will remain under the full control of their national authorities, and they will transfer operational and tactical command and/or control of their forces and personnel to the Commander-in-Chief of the EU Operation, who has the right to delegate his powers.

The participation in the EU operations implies costs that are distributed by the participating countries including the Republic of Serbia. The exception are the costs of the EU operations, which have the military or defence implications.

\section{National legal framework}

The National Security Strategy of the Republic of Serbia emphasizes that, while respecting the interests of preserving its own territorial integrity and sovereignty, the Republic of Serbia, to the greatest extent, harmonizes its foreign and security policy with the EU positions and actions in all major global, 
European and regional issues. Through the European integration process, Serbia expresses its readiness to build the capacities and capabilities of the national security system, in accordance with the standards and obligations arising from the European Security and Defence Policy. Therefore, the National Security Strategy of the Republic of Serbia is harmonized with the EU Security Strategy and it identifies challenges, risks and threats to the security of Serbia, especially in the regional and national context.

The Constitution, as the highest legal act, contains the provisions related to the Armed Forces. It provides for civil and democratic control of the Armed Forces, and also their use outside the country's borders. Such a decision is made by the National Assembly at the proposal of the Government. The decision of the National Assembly on the deployment of the Armed Forces and other defence forces states the name of the multinational operation, the mandate and the total number of the Serbian Armed Forces members who can be deployed in those operations. This body, at the proposal of the Government, decides on the continuation of deployment, i.e. withdrawal of the Serbian Armed Forces members from the multinational operation before the expiration of the mandate in case of its change. On the basis of the decision of the National Assembly, the Government adopts the Annual Plan for the implementation of the deployment of the Serbian Armed Forces and other defence forces in multinational operations, and the President of the Republic makes a decision to deploy the Armed Forces members in accordance with the Assembly decision.

The Law on Defence stipulates that the defence of the Republic of Serbia is conducted, among other things, through the participation of the defence forces in multinational operations and through cooperation with international organizations and institutions, and establishes the obligation of the Serbian Armed Forces members and other defence forces to comply with the rules of international humanitarian law and international standards on the use of force. The character of the obligation is absolute, and the obligation is always valid and in all circumstances, regardless of whether it is a combat or noncombat operation.

The Law on the Serbian Armed Forces, defining the term armed forces, defines in Article 2 that they perform their tasks in accordance with the principles of international law that regulate the use of force.

The Law on engagement of the Serbian Armed Forces and other defence forces in multinational operations outside the Republic of Serbia borders regulates the engagement and preparation of the Serbian Armed Forces for performing missions and tasks in maintaining security and peace in the world and providing humanitarian assistance to other countries in crisis situations, as well as all issues related to that. Apart from it, the issue of the engagement of the Serbian Armed Forces outside the country's borders is regulated by concluded international agreements in the field of security, defence and military cooperation, as well as regulations governing the competences and work of other defence forces. Exceptionally, the Government can approve the participation of other defence forces in humanitarian operations not defined in the Annual Plan, such as in the case of immediate alleviation of the consequences of large-scale natural, technical and technological and environmental disasters, as well as providing assistance to civilian authorities in crisis situations. In order to more efficiently plan, prepare, engage, regularly rotate, withdraw and other activities of the Serbian Armed Forces members, in accordance with the national, security and defence interests of the Republic of Serbia, the Government establishes the Body for the Coordination of Affairs and the Direction of Activities in relation to the participation of the Serbian Armed Forces and other defence forces in multinational operations.

\section{RESPONSIBILITY DURING MULTINATIONAL OPERATION}

The Serbian Armed Forces and other defence forces' personnel only, having completed training in the country or abroad, in possession of relevant training certificate for participation in multinational operations, may be deployed in multinational operations because participation in such operations is specif- 
ic and requires a particular specialty. For every participation of the Serbian Armed Forces members and other defence forces in multinational operations, the rules of engagement prescribed by the United Nations, the European Union or other collective security systems for a specific multinational operation shall be used, provided they do not contradict the principles defined in Article 3 of the Law on engagement of the Serbian Armed Forces in multinational operations. In case of declaration of war or the state of emergency, the Serbian Armed Forces personnel shall not be deployed in multinational operations until the state of war or the state of emergency has ceased to be in force. The exception are operations to alleviate and mitigate the consequences of natural disasters, technical and technological accidents and other accidents that endanger the health and lives of people, material goods and the environment by their scope and intensity, and which cannot be eliminated by engaging the authorities of the state on whose territory the event occurred. The consent of the host country would be conditio sine qua non for the participation of the Serbian Armed Forces members in a multilateral operation. In the case Nicaragua v. the United States, the International Tribunal gives priority to the sovereignty of the state and recognizes the principle of non-intervention as one of the principles of customary international law, stating that respect of international sovereignty is the basis of international relations. The principle of nonintervention was further confirmed by the Declaration of Seven Principles adopted by the UN General Assembly in 1970. In that sense, the issue of initiating humanitarian actions without the consent of the state on whose territory they are carried out raises the question of respect of the principle of sovereignty, and thus the violation of international law. Although there are claims that the condition of obtaining the consent of the host country can be ignored during humanitarian operations because it is not a military but assistance rendering operation, the border has been clearly drawn. ${ }^{3}$ Humanitarian military intervention is intervention based on various political, strategic or security motives of the intervening states, which aims to prevent or stop human rights violations or the suffering of civilian population at war or in peacetime. ${ }^{4}$ Therefore, unilateral humanitarian intervention of one or a group of states is not legal if there is no consent of the state on whose territory it is conducted and the Security Council, no matter how much the reason for intervention seems to be just.

The Serbian Armed Forces members who are engaged in multinational operations and participate in activities are obliged to act in accordance with the Constitution of the Republic of Serbia, law, decisions of competent bodies, principles of international law on the use of force and rules of engagement adopted for a specific multinational operation. The Constitution of the Republic of Serbia emphasizes that generally accepted rules of international law and ratified international agreements are an integral part of the Serbian legal order and are directly implemented. The rules of international law governing the use of force in international relations are contained primarily in the United Nations Charter and customary international law. It should be noted that the Political and Security Committee, the body that conducts political control and strategic direction of crisis management operations, adopted in 2005 the code of conduct in the Common Security and Defence Policy operations, which are not legally binding acts in the EU legal system, but serve as guidelines for the implementation of the rules. The code states that the European Union personnel must implement the rules of international law, including, when applicable, international humanitarian law, i.e. the rules used during an armed conflict.

The United Nations General Assembly also declared the responsibility of the state for internationally illegal acts by adopting the resolution stating that every act of the state contrary to international law has the international responsibility of the state as the consequence. An illegal act of the state means an action, which consists of doing or not doing, that can be attributed to that state according to international law, and represents violation of its international obligations. The qualification of a certain act as contrary to international law is performed according to the rules of international law and that qualification is not affected by its legality according to the rules of national law. According to international law, an act of the state shall be: if a state body or other persons or bodies authorized to exercise elements of the state power act in their official capacity, even if they exceed their powers or act contrary to given instructions; if a person or a group of persons acts according to the instructions of the state, or is under its management or control; if persons or groups of persons actually exercise 
elements of the state power, in the absence or due to the omission of the official authorities, and under circumstances which require such exercise of authority. The circumstances that exclude illegality are valid consent of the state, self-defence and an act of countermeasure to the extent that it has been taken against that state. The responsible state has the obligation to fully compensate all material and non-material damage caused by an act contrary to international law. Full compensation for damage caused by such an act may be given in the form of restitution, financial compensation or satisfaction, either individually or together.

Among the rules of international law that have to be respected are the provisions of the European Convention on Fundamental Rights and Freedoms. Namely, the European Court of Human Rights, as the only authority competent to monitor compliance with the Convention, has confirmed that the legal space of the Convention in certain cases may extend beyond the territory of the Council of Europe member states, i.e. when a member state, through its troops engaged in security operations, exercised such authority and control over individuals that a connection has been established between the competences of the member state and the controlled individuals. This position on the extraterritorial jurisdiction of the members of the European Court of Human Rights indicates that the obligation to respect and protect human rights is not excluded even when it comes to the activities of the state armed forces in multinational operations outside the European contingent, which sets an exception to the territorial validity of the Convention. During the mission outside the borders of the Republic of Serbia, there is the responsibility of the state for all acts performed in the territory of other state by its citizens, members of the mission.

The Court has also dealt with the issue of extraterritorial jurisdiction, i.e. the responsibility of the state for the actions of its soldiers in the territory of other member state, in the case of Pisari v. the Republic of Moldova and Russia, where it pointed out that when state troops are deployed in the territory of other state, the extraterritorial force they use may be extended to the jurisdiction of the state in order to include those affected by the actions of its troops.

In order to attribute the possible illegal behaviour of the soldiers participating in the peace operation to the Union, it would be necessary to determine whether the transferred degree of command and control is proportional to the degree of effective control. Namely, the Serbian Armed Forces members who participate in international operations are still a body of the state of Serbia, while a certain degree of command and control of that body has been transferred to the Union. The members of the Armed Forces and other defence forces have to respect the rules of international law on the use of force and the rules of humanitarian law. They are granted immunity from criminal, civil and administrative jurisdiction of the host country, but are not exempt from the jurisdiction of their own state and are subject to disciplinary, misdemeanour and criminal liability for breaches of duty, in accordance with law and concluded international agreements. It has already been said that during participation in international operations, the Serbian Armed Forces members act as bodies of the state of Serbia and that, according to the agreement with the European Union, they remain under full command of national authorities even when the Union bodies have operational control over their tasks. Thus, it can be concluded that there are grounds for determining the responsibility of the state of Serbia for violations of international law committed by the Serbian Armed Forces members engaged in the Union operations.

It should not be forgotten that international law recognizes the institute of individual criminal responsibility for acts classified as international crime that violate rules based on values of general importance. Therefore, every state is given the right to prosecute and punish the perpetrators of those illegal acts, regardless of whether there is a territorial connection or a connection based on citizenship. This power is extended to inspirers and ordering parties. It is unlikely that forces participating in peacekeeping or crisis management operations will be ordered to commit crimes of genocide or crimes against humanity. Individuals participating in those missions are more likely to violate international humanitarian law and, in compliance with international law, bear personal responsibility for a particular war crime. 
While on a multinational mission, the members of the Serbian Armed Forces and other defence forces are entitled to diplomatic and legal assistance and protection. Diplomatic protection is a traditional institute of international law and means activities that the state uses in exercising diplomatic protection and includes legally permitted procedures by which the other state is informed of its views and requests. Over time, an individual has been given the possibility to file certain petitions or lawsuits demanding respect of their rights.

During an operation, any interference in the internal affairs of the host country and all other activities out of the approved mandate of the mission are prohibited. The Republic of Serbia is obliged to respond to any lawsuits against a member of its staff participating in the EU crisis management operations, and when its responsibility is determined, it pays compensation.

\section{CONCLUSION}

After the Second World War, the integration processes that led to the establishment of the EU began in Europe. Although the non-existence of the EU military force has long been emphasized as evidence of its strength resulting from high-quality normative activity, there is no doubt that the military force behind diplomatic means gives precedence in international relations. The military security and defence is developing in parallel with other integration in Europe. The coming into force of the Lisbon Treaty from 2009 shows that the establishment of other bodies and initiatives necessary for the further development of the EU has been provided.

The development of the Common European Security and Defence Policy is still largely influenced by the NATO because 21 member states of the Union have the NATO membership. The standards implemented by the armed forces of the members are the NATO procedures and standards, which is what the EU members strive for. Setting these standards as a strategic goal of the state contributes to the development of operational capabilities of the Serbian Armed Forces as a whole, which guarantees the efficiency and availability of units for carrying out missions in the country and abroad.

The European Union multinational operations may also include tasks involving the use of force. Such a modality of action is provided for by Article 53 of the United Nations Charter, which provides for the possibility for the Security Council to use regional agreements or agencies to enforce coercive measures. The decisions of the European Union Council that establish, initiate and regulate crisis management operations always refer to the Security Council resolutions in the introductory part.

The engagement of the Serbian Armed Forces and other defence forces in international military operations is possible only in accordance with the Constitution of the Republic of Serbia and international law. The decision is made for each operation with the assessment that the participation of the Armed Forces in that operation is in accordance with national, security, defence and foreign policy interests of the state, i.e. the country's interest to contribute to security at the world, European or regional level taking care about preserving international law and peace. In addition to these external elements important for the country's international reputation, participation in missions has another important aspect - personal experiences and knowledge that the Serbian Armed Forces members acquire during mission, in contact with representatives of other countries.

During mission, adequate legal protection of participants in those operations and compliance with contractual obligations regarding security risk assessment have to be provided. If, within the time allotted for the conduct of an operation, the mandate of the mission is violated, the security and defence interests of the state of Serbia are seriously threatened, or the lives of the Serbian Armed Forces members are endangered, or unacceptable risks and danger to their security arise, a decision on their immediate withdrawal is made before the end of the activity to which they have been sent. The decision on that is made by the National Assembly or, if not possible, the President of the Republic on 
the basis of a proposal given by the Minister of Defence, after joint assessment with competent ministers.

Taking part in an international military mission shows how development and change in modern political relations also affect the armed forces, whose traditional role as a country's defensive force is expanding to preservation of the collective security of the wider community. This requires adjustment to modern international and political relations, and also constant improvement of personnel and technology in order to respond to challenges while respecting all national and international rules governing this field.

\section{Acknowledgement}

The paper was written as a part of the research on the scientific project of the Military Academy of the DefenceUniversity „,The military in the political system of Serbia”, which is financed by the Ministry of Defence of the Republicof Serbia (project number VA-DH/1/19-21).

\section{Endnotes}

'The agreement between the European Union and the Republic of Serbia, which establishes the framework for Serbia's participation in the European Union crisis management operations, was signed on June 8, 2011, and came into force on August 1, 2012.

${ }^{2}$ The Body for the coordination of affairs consists of representatives of the Ministry of Foreign Affairs, the Ministry of Defence, the Ministry of Interior, the Ministry of Finance and the Ministry of Health, and, if necessary, other competent bodies.

${ }^{3}$ The 2005 UN General Assembly World Summit states that it is the duty of each state to protect its citizens from genocide, war crimes, ethnic cleansing and crimes against humanity and approves the intervention of the international community to provide such protection if the state itself cannot or does not want to do it.

${ }^{4}$ The definition of humanitarian intervention of the Institute for International Affairs of the Kingdom of Denmark has been used.

\section{REFERENCES}

1. Magarašević A. Osnovi međunarodnog prava i međunarodnih odnosa. Novi Sad: Zavod za naučnoistraživački rad + Pravni fakultet. 1974. [Google Scholar]

2. Alić G. Humanitarne intervencije i međunarodno pravo. Anali. 2011(21):309-332. [Google Scholar]

3. Jović Ž. Mirovne misije Ujedinjenih nacija i saradnja sa regionalnim akterima. Vojno delo. 2015;67(4):97-107. [SCIndeks] [PDF] [Google Scholar]

4. Keković Z, Komazec N, Milinović M. Uloga Vojske Srbije u odgovoru na nevojne pretnje. Vojno delo. 2011;63(4):228-250. [SCIndeks] [PDF] [Google Scholar]

5. Savić S. Međunarodno pravo i humanitarna intervencija. Međunarodni problemi. 2007;59(1):5-48. [Crossref] [Google Scholar]

6. Stefanović S, Forca B. Preduslovi i neophodne mere za efikasno i efektivno učešće Vojske Srbije u misijama i operacijama zajedničke bezbednosne i odbrambene politike EU. Vojno delo. 2015;67(3):222-250. [SCIndeks] [PDF] [Google Scholar]

7. Nikolić SS. Mirovne operacije Ujedinjenih nacija - prilagođavanje novim bezbednosnim izazovima. Vojno delo. 2016;68(5):7-45. [Crossref] [SClndeks] [PDF] [Google Scholar]

8. Milić T. Međunarodno pravo i učešće pripadnika Vojske Srbije u multinacionalnim operacijama Evropske unije. Vojno delo. 2015;2(15):146-169. [SCIndeks] [PDF] [Google Scholar]

9. Trineke P, Ben C. Military operations and the EU's identity as an international security actor. European Security. 2019;28(4). [Crossref] [Google Scholar]

10. International Law Commission. Draft Articles on the Responsibility of International Organizations, with commentaries. Yearbook of the International Law Commission. 2011;2. [Google Scholar]

11. Reparation for injuries suffered in the service of the United Nations. In: Advisory Opinion, ICJ Reports, 1949. ; p. 178-179. 
12. Responsibility of States for internationally wrongful acts. In: Official Records of the General Assembly, A/RES/56/83, 28 January 2002 on the report of the Sixth Committee, (A/56/589 and Corr.1).

13. Zakon o upotrebi Vojske Srbije i drugih snaga odbrane u multinacionalnim operacijama van granica Republike Srbije. Službeni glasnik RS, br. 88/09, 36/18.

14. Zakon o potvrđivanju Sporazuma između Republike Srbije i Evropske unije o uspostavljanju okvira za učešće Republike Srbije u operacijama Evropske unije za upravljanje krizama, sa izjavama Republike Srbije i država članica Evropske unije o odricanju o. Službeni glasnik Republike Srbije - Međunarodni ugovori. 2012;broj 1260.

\title{
Vojska Srbije kao činilac međunarodne saradnje i evrointegracija
}

\begin{abstract}
Sažetak:
Zaključivanjem međunarodnih ugovora u oblasti bezbednosti i odbrane, Vojska Srbije postaje činilac međunarodne saradnje, što državi nameće određene odgovornosti i, na poseban način, uređuje međunarodnopravni položaj njenih pripadnika. U radu su predstavljeni nastanak i razvoj ideje o zajedničkoj evropskoj odbrani i bezbednosti, obaveze Republike Srbije i domaći pravni okvir koji reguliše ovu oblast. Cilj Zajedničke spoljne i bezbednosne politike EU, uspostavljene Ugovorom iz Mastrihata, jeste očuvanje mira i jačanje međunarodne bezbednosti u skladu sa principima iz Povelje Ujedinjenih nacija. Da bi taj cilj bio ostvariv, pristupilo se razvoju Zajedničke politike bezbednosti i odbrane, kojom Unija preuzima vodeću ulogu u mirovnim operacijama i sprečavanju konflikta. Analizom sadržaja domaćih i međunarodnih akata prikazan je evolutivni razvoj ideje o postojanju kolektivne bezbednosti, doneti su akti za njeno sprovođenje i uslovi potrebni za uspešno izvršenje postavljenih zadataka. Takođe, korišćeni su komparativni i istorijski metod, kao i metod dedukcije. Može se zaključiti da nova oblast integracija u Evropi uslovljava da oružane snage država članica dobijaju ulogu u međunarodnim odnosima pokrećući niz institucionalnih reformi i promenu shvatanja društvene uloge vojske. Međunarodno vojno angažovanje na regionalnom i globalnom nivou, uz bilateralnu saradnju, sredstvo je za otklanjanje pretnji nacionalnoj bezbednosti uz ojačavanje sposobnosti nacionalnog sistema odbrane. Da bi takvo angažovanje bilo legitimno neophodno je ispuniti stroge uslove.
\end{abstract}

Ključne reči: Zajednička politika bezbednosti i odbrane; Evropska unija; Vojska Srbije 